\title{
SARS-CoV-2: low virus load on surfaces in public areas
}

\author{
Konstantin Zedtwitz-Liebenstein ${ }^{1}$ (D)
}

Received: 5 July 2021 / Accepted: 1 January 2022 / Published online: 8 January 2022

(c) The Author(s), under exclusive licence to Springer-Verlag GmbH Germany, part of Springer Nature 2022

\begin{abstract}
Severe Acute Respiratory Syndrome Coronavirus 2 (SARS-CoV-2) has led people to implement preventive measures, including surface and hand disinfection with a disinfectant to avoid viral transmission. The detection of coronaviruses on surfaces implies not always a high danger of infection. Different coronaviruses and SARS-CoV-2 can be detected under experimental conditions on surfaces for many days. However, there are no studies concerning the virus load and the risk for an infection. The aim of our study was to find out if we could detect SARS-CoV-2 with a virus load greater than $10^{6}$ copies $/ \mathrm{mL}$ in public areas under real-life conditions. A total of 1200 swabs were performed on different environmental surfaces in public areas: handholds, press buttons in buses, tramways, tubes, elevators, shops, doorknobs in public buildings, public restrooms, touchscreens in shops and public transportation services, supermarket trolleys, banknotes and coins and immediately tested. We used Rapid Covid-19 Antigen Test (Clinitest ${ }^{\circledR}$ ) by Siemens Healthineers (Healgen Scientific Limited Liability Company, Houston, USA, respectively, Shanghai International Holding Corp. GmbH (Europe), Hamburg, Germany). During our study, we were not able to detect SARS-CoV-2 with a virus load greater than $10^{6}$ copies $/ \mathrm{ml}$ although we pooled the swabs. According to the negative antigen tests and with a theoretically probability calculation of $1 / 24.000$, there seems no relevant risk of infection with SARS-CoV-2 in public areas. For people with underlying diseases or immunosuppression, the risk of transmission respectively infectivity cannot be excluded with this study.
\end{abstract}

Keywords SARS-CoV-2 $\cdot$ Low virus load $\cdot$ Public areas

\section{Introduction}

Severe Acute Respiratory Syndrome Coronavirus 2 (SARSCoV-2) has led people to implement preventive measures including surface and hand disinfection to avoid viral transmission. Environmental conditions can affect coronavirus survival for until 28 days on different surfaces (Marzoli et al. 2021).

However, there are no studies concerning the virus load and the risk for an infection. The aim of our study was to find out if it is possible to detect SARS-CoV-2 with a virus load greater than $10^{6}$ copies $/ \mathrm{ml}$ in public areas under reallife conditions.

Responsible Editor: Lotfi Aleya

Konstantin Zedtwitz-Liebenstein

konstantin.zedtwitz-liebenstein@gesundheitsverbund.at

1 Head Office of Vienna Hospital Association, Thomas Klestil Platz 7, 1030 Vienna, Austria

\section{Material and methods}

\section{Study design}

The study was performed between January and April 2021 during the rush hour in the morning and the evening in different public areas. The average outside temperature during this time was $4.7^{\circ} \mathrm{C}$ (range $-8.4{ }^{\circ} \mathrm{C}$ to $25.3^{\circ} \mathrm{C}$ ).

The surface swabbing was performed on different environmental surfaces in public areas: handholds, press buttons in buses, tramways, tubes, elevators, shops, supermarket trolleys or doorknobs in public buildings, public restrooms, touchscreens in shops and public transportation services, banknotes and coins.

Because of negative test results at the beginning of the study, we decided to pool 20 swabs in one extraction tube which contains $0.3 \mathrm{ml}$ of the extraction buffer. The tests were performed in consideration with the sample preparation procedure.

We used Rapid Covid-19 Antigen Test (Clinitest $\left.{ }^{\circledR}\right)$ by Siemens Healthineers (Healgen Scientific Limited Liability 
Table 1 Survival of different coronaviruses on different surfaces

\begin{tabular}{llll}
\hline Surface & Type of virus & Survival (days) & References \\
\hline $\begin{array}{l}\text { Metal, surfaces of polymer and paper } \\
\text { banknotes }\end{array}$ & SARS-CoV-2 & 28 & Riddell et al. 2020 \\
$\begin{array}{l}\text { Glass and paper } \\
\text { Face mask days }\end{array}$ & SARS-CoV-2 & 28 & Riddell et al. 2020 \\
Banknotes & SARS-CoV-2 & 7 & Chin et al. 2020 \\
Polymer and plastic banknotes & SARS-CoV-2 & 4 & Chin et al. 2020 \\
Mosaic and soil & SARS-CoV-2 & 28 & Riddell et al. 2020 \\
Polymer surfaces & SARS-CoV & $3-4$ & Duan et al. 2003 \\
Sponge & SARS-CoV & 13 & Chan et al. 2011 \\
Ceramic & Coronavirus & 1 & Sizun et al. 2000 \\
Glass surfaces at $20{ }^{\circ} \mathrm{C}$ & Coronavirus & 5 & Warnes et al. 2015 \\
\hline
\end{tabular}

Company, Houston, USA, respectively, Shanghai International Holding Corp. GmbH (Europe), Hamburg, Germany). This assays showed a specificity of $100 \%$ and a sensitivity Confidence Intervall 95 (CI) of 54.9\% (43.3-65.9). This test was consequently able to detect $10^{6}$ copies $/ \mathrm{mL}$ (Olearo et al. 2021).

\section{Results}

During our study, 1200 swabs were performed but all antigen tests were negative. Although we pooled 20 swabs in one extraction tube, we were not able to detect SARS-CoV-2 with a virus load greater than $10^{6}$ copies $/ \mathrm{mL}$.

With a theoretically probability calculation of $1 / 24.000$, we decided to stop this study. In summary, the high count of performed swabs with the pooling procedure could show that the probability to find a high virus load is rare.

\section{Discussion}

SARS-CoV-2 transmission like other coronaviruses occurs by direct or indirect contact with nasal, conjunctival or oral mucosa, when virus particles are inhaled or deposited on these mucous membranes. Virus receptors are found mainly in the human respiratory tract epithelium, including the oropharynx and upper airway. The conjunctiva and gastrointestinal tract are also susceptible to infection and may serve as transmission portals (Stadnytskyi et al. 2020; Zhang et al. 2020).

SARS-CoV RNA shedding persists in the upper respiratory tract and in faeces for more than 1 month after illness onset (Cevik et al. 2020a, 2020b). However, virus isolation has rarely been successful from the stool (Cevik et al. 2020a, 2020 b) and faecal-oral transmission is not considered a primary driver of infection (Cevik et al. 2021).

Evidence of viral transmission from contaminated surfaces has been shown in the case of enteric viruses (Boone and Gerba 2007), but in contrast, evidence specifically referring to SARS-CoV-2 is missing.

Studies concerning survival time of different coronaviruses on surfaces showed that the virus can be detected under experimental conditions for many days (Table 1). In these studies, no virus load was performed which is necessary to evaluate the risk of transmission respectively infectivity.

Generally, surface and environment disinfection is necessary in hospital settings because the possibility of coronavirus transmission from contaminated dry surfaces to individuals exists (Dowell et al. 2004; Otter et al. 2016).

Environmental factors such as temperature, moisture, exposure to UV and surface characteristics also affect virus survival on surfaces (Boone and Gerba 2007). High temperature and high relative humidity have a synergistic effect on inactivation of SARS-CoV and SARS-CoV-2 viability, while low temperatures and low relative humidity support prolonged survival of these viruses on contaminated surfaces (Biryukov et al. 2020; Chan et al. 2020, 2011; Van Doremalen et al. 2013).

In the beginning of the study, we had to decide which test should be the best for this investigation. PCR or Antigen test. The PCR test has a high sensitivity and specificity that can detect small numbers of viral RNA. Recent studies involving upper respiratory swab specimens reported no cases of COVID19 transmission with SARS-CoV-2 viral RNA loads $<10^{4}$ copies $/ \mathrm{mL}$. Others showed that specimens with viral RNA loads $\leq 10^{6}$ copies $/ \mathrm{mL}$ have a low probability of having culturable SARS-CoV-2 virus (Pekosz et al. 2021).

We decided to use a rapid antigen test, which implies current infection with SARS-CoV-2 (Verma et al. 2020). The sensitivity of this rapid antigen detection test (Ag-RDT) increases when testing samples with higher RNA virus concentration (Warnes et al. 2015). Although the correlation between virus load and transmissibility is not entirely clear, several studies showed that samples with a virus load $\geq 10^{6}$ 
RNA copies/mL were likely to correlate with infectivity in cell culture models (Kohmer et al. 2021).

We stopped this study because all antigen tests were negative. The high count of performed swabs with the pooling procedure could show that the probability to find infectious SARS-CoV-2 viral RNA with a virus load $\geq 10^{6}$ copies $/ \mathrm{mL}$ must be rare or improbably.

Further studies concerning transmissibility of SARSCoV-2 viral RNA with a virus load $<10^{6}$ copies $/ \mathrm{mL}$ in people with a limited immune system, underlining diseases or immunosuppressive therapy are necessary. The risk of transmission respectively infectivity cannot be excluded for these people with this study.

\section{Conclusion}

With a theoretically probability calculation of $1 / 24.000$ and the missing detection of SARS-CoV-2 viral RNA with a virus load $\geq 10^{6}$ copies $/ \mathrm{mL}$, there seems no relevant risk of infection in public areas. For people with underlying diseases or immunosuppression, the risk of transmission respectively infectivity cannot be excluded with this study.

Availability of data and materials Data and materials are available by the author.

\section{Declarations}

Ethical approval Not applicable.

Consent to participate Not applicable.

Consent to publish Not applicable.

Competing interests The author declares no competing interests.

\section{References}

Biryukov J, Boydston JA, Dunning RA, Yeager JJ, Wood S, Reese AL, Ferris A, Miller D, Weaver W, Zeitouni NE, Phillips A, Freeburger D, Hooper I, Ratnesar-Shumate S, Yolitz J, Krause M, Williams G, Dawson DG, Herzog A, Dabisch P, Wahl V, Hevey MC, Altamura LA. (2020) Increasing temperature and relative humidity accelerates inactivation of SARS-CoV-2 on surfaces. mSphere. 5(4):e00441-20. doi: https://doi.org/10.1128/mSphe re.00441-20.

Boone SA, Gerba CP (2007) Significance of fomites in the spread of respiratory and enteric viral disease. Appl Environ Microbiol 73(6):1687-1696. https://doi.org/10.1128/AEM.02051-06

Cevik M, Bamford CGG, Ho A (2020a) COVID-19 pandemic-a focused review for clinicians. Clin Microbiol Infect 26(7):842847. https://doi.org/10.1016/j.cmi.2020.04.023
Cevik M, Kuppalli K, Kindrachuk J, Peiris M (2020b) Virology, transmission, and pathogenesis of SARS-CoV-2. BMJ 371:m3862. https://doi.org/10.1136/bmj.m3862

Cevik M, Tate M, Lloyd O, Maraolo AE, Schafers J, Ho A (2021) SARS-CoV-2, SARS-CoV, and MERS-CoV viral load dynamics, duration of viral shedding, and infectiousness: a systematic review and meta-analysis. Lancet Microbe 2(1):e13-e22. https://doi.org/10.1016/S2666-5247(20)30172-5

Chan KH, Sridhar S, Zhang RR, Chu H, Fung AY, Chan G, Chan JF, To KK, Hung IF, Cheng VC, Yuen KY (2020) Factors affecting stability and infectivity of SARS-CoV-2. J Hosp Infect 106(2):226-231. https://doi.org/10.1016/j.jhin.2020.07.009

Chan KH, Peiris JS, Lam SY, Poon LL, Yuen KY, Seto WH (2011) The effects of temperature and relative humidity on the viability of the SARS coronavirus. Adv Virol. 734690. https://doi.org/ 10.1155/2011/734690.

Chin AWH, Chu JTS, Perera MRA, Hui KPY, Yen HL, Chan MCW, Peiris M, Poon LLM (2020) Stability of SARS-CoV-2 in different environmental conditions. Lancet Microbe 1(1):e10. https:// doi.org/10.1016/S2666-5247(20)30003-3

Dowell SF, Simmerman JM, Erdman DD, Wu JS, Chaovavanich A, Javadi M, Yang JY, Anderson LJ, Tong S, Ho MS (2004) Severe acute respiratory syndrome coronavirus on hospital surfaces. Clin Infect Dis 39(5):652-657. https://doi.org/10.1086/422652

Duan SM, Zhao XS, Wen RF, Huang JJ, Pi GH, Zhang SX, Han J, Bi SL, Ruan L, Dong XP, SARS Research Team (2003) Stability of SARS coronavirus in human specimens and environment and its sensitivity to heating and UV irradiation. Biomed Environ Sci. 16(3):246-55.

Kohmer N, Toptan T, Pallas C, Karaca O, Pfeiffer A, Westhaus S, Widera M, Berger A, Hoehl S, Kammel M, Ciesek S, Rabenau HF (2021) The comparative clinical performance of four SARS$\mathrm{CoV}-2$ rapid antigen tests and their correlation to infectivity in vitro. J Clin Med 10(2):328. https://doi.org/10.3390/jcm10 020328

Marzoli F, Bortolami A, Pezzuto A, Mazzetto E, Piro R, Terregino C, Bonfante F, Belluco S (2021) A systematic review of human coronaviruses survival on environmental surfaces. Sci Total Environ 778:146191. https://doi.org/10.1016/j.scitotenv.2021. 146191

Olearo F, Nörz D, Heinrich F, Sutter JP, Roedl K, Schultze A, Wiesch JSZ, Braun P, Oestereich L, Kreuels B, Wichmann D, Aepfelbacher M, Pfefferle S, Lütgehetmann M (2021) Handling and accuracy of four rapid antigen tests for the diagnosis of SARSCoV-2 compared to RT-qPCR. J Clin Virol 137:104782. https:// doi.org/10.1016/j.jcv.2021.104782

Otter JA, Donskey C, Yezli S, Douthwaite S, Goldenberg SD, Weber DJ (2016) Transmission of SARS and MERS coronaviruses and influenza virus in healthcare settings: the possible role of dry surface contamination. J Hosp Infect 92(3):235-250. https://doi.org/ 10.1016/j.jhin.2015.08.027

Pekosz A, Parvu V, Li M, Andrews JC, Manabe YC, Kodsi S, Gary DS, Roger-Dalbert C, Leitch J, Cooper CK (2021) Antigen-based testing but not real-time polymerase chain reaction correlates with severe acute respiratory syndrome coronavirus 2 viral culture. Clin Infect Dis. ciaa1706. https://doi.org/10.1093/cid/ciaa1706. Online ahead of print.

Riddell S, Goldie S, Hill A, Eagles D, Drew TW (2020) The effect of temperature on persistence of SARS-CoV-2 on common surfaces. Virol J 17(1):145. https://doi.org/10.1186/s12985-020-01418-7

Sizun J, Yu MW, Talbot PJ (2000) Survival of human coronaviruses 229E and OC43 in suspension and after drying on surfaces: a possible source of hospital-acquired infections. J Hosp Infect 46(1):55-60. https://doi.org/10.1053/jhin.2000.0795

Stadnytskyi V, Bax CE, Bax A, Anfinrud P (2020) The airborne lifetime of small speech droplets and their potential importance 
in SARS-CoV-2 transmission. Proc Natl Acad Sci U S A 117(22):11875-11877. https://doi.org/10.1073/pnas.2006874117

Van Doremalen N, Bushmaker T, Munster VJ (2013) Stability of Middle East respiratory syndrome coronavirus (MERS-CoV) under different environmental conditions. Euro Surveill 18(38):20590. https://doi.org/10.2807/1560-7917.es2013.18.38.20590

Verma N, Patel D, Pandya A (2020) Emerging diagnostic tools for detection of COVID-19 and perspective. Biomed Microdevices 22(4):83. https://doi.org/10.1007/s10544-020-00534-z

Warnes SL, Little ZR, Keevil CW (2015) Human coronavirus 229E remains infectious on common touch surface materials. mBio. 6(6):e01697-15. https://doi.org/10.1128/mBio.01697-15.
Zhang R, Li Y, Zhang AL, Wang Y, Molina MJ (2020) Identifying airborne transmission as the dominant route for the spread of COVID-19. Proc Natl Acad Sci U S A 117(26):14857-14863. https://doi.org/10.1073/pnas.2009637117

Publisher's note Springer Nature remains neutral with regard to jurisdictional claims in published maps and institutional affiliations. 